\title{
Effect of Lean Accounting on the Effectiveness of Internal Control in Jordanian Industrial Companies
}

\author{
Atallah Ahmad Alhosban ${ }^{1, *}$, Mohammed Alsharairi \\ ${ }^{1}$ Aqaba University of Technology, Financial and Managerial College, Accounting, Aqaba, Jordan \\ ${ }^{2}$ Financial and Managerial College, Irbid National University, Accounting, Irbid, Jordan
}

Email address:

aalhosban@gmail.com (A. A. Alhosban)

${ }^{*}$ Corresponding author

To cite this article:

Atallah Ahmad Alhosban, Mohammed Alsharairi. Effect of Lean Accounting on the Effectiveness of Internal Control in Jordanian Industrial Companies. International Journal of Business and Economics Research. Vol. 8, No. 3, 2019, pp. 153-160. doi: 10.11648/j.ijber.20190803.19

Received: April 25, 2019; Accepted: June 4, 2019; Published: June 27, 2019

\begin{abstract}
The study aimed at explaining the effect of the use of lean accounting on the internal control components, namely accounting control and administrative control. A questionnaire was designed to achieve the objectives of the study. The study community shall be the internal auditors of the Jordanian industrial companies, which shall participate in the primary market only. The most important results of the study The industrial companies are based on the restructuring of their products from time to time based on customer requests, and this contributes to the achievement of financial control and accounting for production costs, and The industrial companies shift the reduction of production costs by reducing the cost of inventory to the lowest levels in order to control the assets and safety of the company and maintain a certain level of quality in the financial statements. the most important recommendations of the study: The need to achieve self-control of manufacturing processes by taking the target price and target cost, and the necessity of achieving the best product for the customers in terms of quality and the appropriate price, which affects positively on the achievement of cost control through the work of planning budgets.
\end{abstract}

Keywords: Lean Accounting, Internal Control, Accounting Control, Managerial Control

\section{Introduction}

The philosophy of applying lean accounting in industrial companies comes from the need for modern administrative means that have an efficient and effective effect on increasing productivity and reducing the cost of production of goods or services in general, increasing flexibility in production and processing costs and providing additional value to customers, whether at the right price or adding desires and needs. To provide them with the service or product required by the target group of customers, to increase the positive results of the financial position of the company and to increase cash inflows and outflows to ultimately maximize the market value of the company in general in the financial markets. [1]

These requirements are collectively prerequisites for the globalization of financial markets and to remain competitive as long as possible, as financial markets are facing new issues of product quality development and increased opportunities and flexibility of the product or service industry to meet the demands of both competitors and customers. we must meet these requirements by changing operational strategies to meet the requirements of applying lean accounting terms and principles. lean accounting is a multidimensional philosophy based on the collection of ideas to facilitate modern management practices including zero stock (access to the value of storage costs of products zero) and product quality system for both goods or services and increase the efficiency of teamwork within the company strategy and the work of an integrated management system Procurement processes for the company or establishment. [2]

\subsection{The Problem of the Study}

This study attempts to answer the following question: "What is the use of computer technology and electronic auditing programs to increase the efficiency of external auditors in Jordan?

The elements of the study problem are 
i What is the impact of the use of electronic work environment technology to increase the efficiency of external auditors in Jordan?

ii ii. What is the impact of the use of electronic auditing programs on increasing the efficiency of external auditors in Jordan?

\subsection{Hypotheses of the Study}

Based on the study problem, the following hypotheses can be formulated:

$i$ There is no effect on the use of lean accounting on the effectiveness of accounting control in the Jordanian industrial joint stock companies.

ii There is no effect on the use of lean accounting on the effectiveness of administrative control in the Jordanian industrial companies?

\subsection{Importance of Studying}

lean Accounting is a modern management methods based on the existence of an integrated team of several competencies contribute to the definition of items of the cost of service or goods so that they are considered from the beginning stages of service design and to follow up the submission of the customer and the process of updating them according to the expectations of customers and the market, This team of several specialties contributes to the real cost of services, which makes it easy to determine the prices of those services with reliability and stability.

\subsection{Objectives of the Study}

This study seeks to achieve the following objectives

$i$ Identifying the effect lean accounting on the effectiveness of accounting control in Jordanian industrial companies.

ii To recognize the effect of lean accounting on the effectiveness of administrative control in the Jordanian industrial companies

\subsection{Previous Studies}

1. Najm study (2019) "the impact of the use of lean accounting on the planning of production processes in the Jordanian industrial companies"

This study aimed at identifying the impact of the use of flexible accounting tools (continuous improvement, value stream maps, point fund, Hoshin policy) on the planning of production costs in the Jordanian joint stock companies listed on the Amman Stock Exchange. The study was composed of accountants, account managers, financial managers and internal auditors of 64 companies listed on the Amman Stock Exchange. The sample size was 29 companies, and 195 questionnaires were distributed, of which 168 were retrieved. The study was based on a questionnaire distributed to accountants, internal auditors and financial managers in industrial companies. Questionnaires were distributed to 29 companies. Statistical methods such as arithmetic mean, standard deviation, natural distribution test, and sample test were used. The most important results of the study: The use of the method of continuous improvement and the method of value stream maps and the method of the points fund and the policy of Hoshin have a positive impact on the planning costs of production operations in the Jordanian industrial joint stock companies. The most important recommendations are: the need to qualify cadres in industrial companies with the necessary professional certificates on the subject of auditing or accounting grace, and the need to organize conferences that contribute to the definition of agile accounting and the definition of the benefits to industrial companies. [2]

2. Mohammed AL-Sharairi1, Atallah Al-Hosban \& Hussam Thnaibat (2018) "The impact of the Risks of the Input of Accounting Information Systems on Managerial Control, Accounting Control and Internal Control in Commercial Banks in Jordan

The study aimed at determining the impact of the risks of the input of the accounting information systems on the accounting control, administrative control, and internal control. The questionnaire was used to obtain the study data. The study community consisted of internal auditors in commercial banks. Statistical methods were used such as: arithmetic mean, standard deviation, and Kronbach Alpha test. The most important results of the study: the impact of the risks of accounting information systems on administrative control and accounting control and internal control. One of the most important recommendations: the need to document all the data of the accounting system, and the need to train staff on how to reduce the risks of accounting information systems in general. [3]

3. Sief, AbdAjhaleel (2018) "Using lean Accounting Tools to Measure and Evaluate Performance in Health Units in Mosul City,

The term is Lean, which came originally from the thought of grace and from this point the researcher tried to perform a performance evaluation of one of the health Sectors using one of the methods. The researcher has hypothesized two basic hypotheses that there is a real waste of health Sectors resources. If the performance fund is used in the health Sectors, it will eliminate a In conclusion, the researcher concluded that there is a real waste in the health Sectors caused by the lack of control of resources in the first place and the lack of an efficient system that can control the disposal of materials and equipment The researcher recommended the implementation of the performance fund and its details in the internal control and auditing unit, which will positively affect the performance of the health Sectors. [4]

4. Awadallah study (2018) entitled "The effect of integration between resource consumption accounting and the cost effective accounting system in reducing costs - field study in the Sudan industrial companies.

The purpose of this study was to learn the importance of using the tools of integration between the methods of accounting for the consumption of another commodity (inventory) and the use of the accounting system to reduce the cost of producing goods in the industrial sector in Sudan. 
It also aimed at examining the evolution of cost systems and the impact of the shift from traditional cost methods to modern cost methods and the impact on reducing production costs. The deductive approach was used to obtain information in addition to the historical method by tracking production costs as some industrial companies shifted from traditional cost systems to modern manufacturing systems. Statistical methods, such as the Kronbach alpha test, were used to find the degree of internal consistency of the responses of the individuals in the study sample and the mean and standard deviation were used.

The review of cost systems and their updating from time to time has a positive impact on the reduction of product costs in Sudanese industrial companies. The integration of inventory accounting and the lean accounting system has a positive effect on reducing inventory costs and optimizing the use of industrial companies' resources. The most important recommendations are: the need to carry out continuous development of manufacturing processes in order to reduce the cost of production to reach the real cost of products, focusing on the subject of costs from the beginning stages of manufacturing processes for products either from the design of products until the exit of the final product available to buy from the customer, Reduce production costs. [5]

4-Daferighe (2018) entitled "Lean Accounting and Waste Management in Brewery Industry in Nigeria.

The role of lean accounting in the management of lost production in industrial companies in Nigeria.

The objective of the study was to define the role of lean accounting in the management of lost production in the industrial companies in Nigeria, and to define the theoretical framework for lean management and flexible accounting and their role in influencing production costs. The study relied on the questionnaire to obtain preliminary data from the study sample of accountants and production management in the industrial companies in Nigeria. The arithmetic mean was used to express the paragraphs of the questionnaire or to discuss the hypotheses of the study. The smaller squares were used to test the hypotheses of the study. A total of 50 questionnaires were distributed on the sample of the study which were valid for the purposes of statistical analysis. One of the most important results of the study is that the practice of prudent accounting does not significantly affect the reduction of the cost of products in industrial companies because the industrial companies in Nigeria do not apply the correct theoretical concept in industrial companies. The results of the study also showed that lean accounting did not affect the reduction of production costs Industrial Companies. The most important results are: the need to train employees in general and accountants and financial managers on the methods and methods of lean accounting because of the advantages achieved by the industrial and service companies, in addition to the need to adopt regulations and instructions to adopt modern cost systems in industrial companies. [6]

\section{The Theoretical Framework of the Study}

lean accounting is a general term used to find the required change in the accounting methods used in the company, to achieve the best methods of control, measurement of accounting elements of the financial statements, and to improve processes and administrative practices to reach the production of the company and increase the company's profits by reducing production costs without affecting the quality of the product or service. [7]

the term "lean accounting" is the general term used for the changes required in the unit Circuit operations support lean manufacturing and slim thinking, as most units are transformed Accounting, control and measurement To fitness quickly find significant changes in management methods because they are at odds with the methods of fitness that they do Units, due to the fact that those units have been designed with traditional accounting systems in line with the wide production or Massive, while graceful practices break these rules and are on the opposite side of mass production but production According to the demand or so-called withdrawal system, and therefore the traditional accounting systems in the "best case" is not appropriate with And may be highly hostile to the agile changes of the economic unit. [8]

\subsection{Manage Cost System Using Lean Accounting}

The cost management strategy in legacy systems is based on reducing production costs based on reduced product quality. When using lean accounting, the cost system is done as follows [9]:

1. Inventory costs are the lowest point because soft production depends on customers' requests rather than market demands.

2. Direct labor costs are at their lowest levels and indirect costs play an important role in lean manufacturing.

3. The products are remodeled during the production processes, which contributes to reducing the loss or loss as much as possible.

4. lean industrialization grows with relative stability in the size of a single point and this helps reduce lost time or time of transportation for production inputs.

\subsection{Steps to Use Lean Accounting}

The application of lean accounting depends on the following steps: [10]

1. Develop tools that link value flows to strategic objectives.

2. Analysis of elements and data on production costs that have a positive impact on the application of agile accounting.

3. Eliminate complex production processes from financial transactions as much as possible.

4. The process of finding the right price for a commodity or service depends on market factors and the determination of the break-even point and the 
competitive markets.

\subsection{Characteristic Features of Lean Accounting}

There are characteristics or attributes of lean accounting that can be summarized as follows: [11]

1. It prepares reliable and consistent data and information for decision-making.

2. To reduce costs as much as possible by reducing the costs of waste or waste in the production process.

3. It focuses on the strategy of the company, which depends on the overall financial savings and maximizes profits.

4. Provide optimal service to customers and try to maintain them and increase their preparation.

\subsection{Effectiveness of Internal Control}

Characteristics of the effective internal control system

The effectiveness of a good internal control system must have the following characteristics: [12]

1. The system should be compatible with the strategic objectives of the institution so that there is flexibility or suitability between the designs of the internal control system with the objectives of the establishment

2. There should be an application of the cost and benefit policy so that there is a balance between the costs of design of the internal control system and the returns from those costs through the application of economic feasibility

3. The presence of the element of detail or clarity in determining the methods and purpose of control and identify deviations and justifications

4. The flexibility of the regulations and instructions according to developments in the internal environment or the external environment and have an impact on the objectives of the establishment.

\subsection{Effectiveness of Internal Control}

Characteristics of the effective internal control system

The effectiveness of a good internal control system must have the following characteristics: [12]

1. The system should be compatible with the strategic objectives of the institution so that there is flexibility or suitability between the designs of the internal control system with the objectives of the establishment

2. There should be an application of the cost and benefit policy so that there is a balance between the costs of design of the internal control system and the returns from those costs through the application of economic feasibility

3. the presence of the element of detail or clarity in determining the methods and purpose of control and identify deviations and justifications

4. The flexibility of the regulations and instructions according to developments in the internal environment or the external environment and have an impact on the objectives of the establishment.

\subsection{Conditions of Effective Control System}

Any effective control system must meet the following conditions: [13]

1. Harmonization between the nature of the internal welfare system with the nature of activities that are monitored, and this depends on the size and diversity and the complexity of the products of the establishment or services provided to customers

2. The system provides indicators to detect deviations before they occur or moment of occurrence so that the company can manage to correct the course of deviations and mitigate the negative risks as much as possible

3. There is flexibility in the design and implementation of internal control system so that the system can be changed according to developments in the environment of the establishment or changes that may affect the activities

4. Ensure the integrity of the performance of the control functions as planned and ensure that the expected costs of the internal control system are maintained from the application of the balance of costs with benefits in the event of deviations from the implementation of any plan.

\subsection{Evaluate the Effectiveness of the Internal Control System}

The process of evaluating the effective internal control system is as follows: [13]

1. Provide data and facts on the nature of the reulatory system, which is consistent with the strategy of the establishment and ensure the adequacy of the data with the organization's organizational structure

2. Ensure the correct operation of the facts provided to ensure the effectiveness of data and facts used in the design of the internal control system

3. Ensure proper implementation of internal control procedures with predefined standards through the use of document review and verification of balances

4. Overall evaluation of the system through regular interconnection between previous elements and comparison of actual results with expected results.

\subsection{Effectiveness of Internal Control Departments}

First: Effectiveness of accounting and administrative control Accounting is defined as a control that seeks to achieve a control over the financial and accounting regulations and instructions that aim to preserve the integrity of the assets of a certain establishment and to ensure the integrity of the financial statements of accounting errors. This means that the accounting control achieves general control and control of applications. This control is intended to ensure that the management's orders are implemented legally, that the financial operations are recorded historically and according to the accounting principles, the proper use of the assets of the establishment, and the conformity of the assets of the actual establishment with what is recorded in the books. [14] 
The effectiveness of financial and administrative control depends on the following: [15]

1. Track the financial operations and accounting processes from the original document until the end of that process in the financial statements and this ensures the correct application of generally accepted accounting principles

2. The efficiency of employees working in financial and accounting work, where this factor is important to any system since the system of control in general depends on the efficiency of staff in terms of design, implementation and control

3. Separation of the conflicting functions between employees so that one employee is not allowed to register and the migration and preparation of financial statements alone, which means there is more than one employee to prepare the financial process

4. Provide a physical protection system for the assets of the establishment is a safe place and the use of electronic controls to maintain the assets of the establishment

Second, the effectiveness of administrative control

This control is based on the organizational plan to ensure the proper implementation of the administrative policies by the management of the establishment in order to achieve the productivity of these policies. This control is done through statistical analysis of financial statements, the preparation of estimates and standard costs and the use of charts and performance reports. On the health and safety of financial and accounting controls. [16]

The effectiveness of administrative and financial control depends on the following factors: [16]

1. Provide a set of performance reports that aim to identify the negative or positive deviations between the actual and the planned these measures are preventive control through the system of planning budgets and standard costs, and these reports are the basis for the success of administrative control

2. There is consistency between the employees in the completion of their work so that the work of staff through a regular coordination depends on the sequence of power lines based on the proper organizational structure, which determines the nature of the organizational relationship between staff and methods of applying the principle of management exception and the preparation of planning budgets.

3. -Performance reports appropriate to the feedback method that have a positive impact on the implementation of administrative policies by the staff and the efficiency of its application to achieve the objectives of the establishment, and aims to identify persons responsible for any defect in the preparation, design or implementation of the organizational plan.

\section{Statistical Analysis}

\subsection{Society and Study Sample}

The sample and sample of the study consists of Jordanian industrial joint stock companies listed on the Amman Stock Exchange. The sample of the study consists of the internal auditors of the public industrial companies in the first market. The number of industrial companies listed on the Amman Stock Exchange for the financial markets is 29 companies. The internal auditors of these companies were 86 internal auditors. The samples were distributed using the simple sample method, 77 questionnaires were distributed and 69 valid questionnaires were retrieved for statistical analysis.

\subsection{Methods of Data Collection}

In order to achieve the objectives of the study and to test the hypotheses on which it was built, the researcher deals with two types of data, primary data and secondary data, as follows:

First. Preliminary data: The inputs obtained through the field distribution of the questionnaire on industrial companies listed on the Amman Stock Exchange.

Second. Secondary data: which are scientific books related to the subject of study in addition to the master's thesis and scientific research court, specifically the following sources were used:

1. Scientific and methodological books related to the tools of accounting and agile planning production processes

2. Specialized international journals and publications related to the study or its variables or objectives.

3. Thesis (Master and $\mathrm{PhD}$ ).

\subsection{Data Collection Tool, Honesty and Consistency}

The researcher designed a questionnaire for the current study in a way that covers the hypotheses on which it was based and using evaluative expressions to determine the answers of the sample of the study to the questions specified in the questionnaire. The study tool consists of two main sections:

Section 1: The demographic variables related to the following: "Years of experience, scientific specialization and qualifications)

Section II: This is the study areas and the paragraphs of the questionnaire containing the variables

\subsection{Reliability}

The opinions of the arbitrators were taken with experience and specialization from the accounting department in private universities and government universities to ensure the existence of the degree of honesty in the paragraphs and statements of the questionnaire, was also retrieved questionnaires and make appropriate adjustments to arrive at the questionnaire in its final form.

\subsection{Kronbach Alpha}

For the stability of the tool, the questionnaire gives the same results if it is applied several times in a row. It also means to what degree the meter gives close readings at each time it is used, or its degree of consistency, consistency and continuity when repeated in different times. Therefore, the 
researcher used the Kronbach Alpha (Cronpach's Alpha) for internal consistency, to determine the degree of dependence on the questionnaire. The Kronbach alpha coefficient was extracted for the internal consistency of all axes and resolution paragraphs. The degree of reliability of this

\subsection{Characteristics of the Study Sample}

\subsubsection{Characteristics of Study Sample Individuals}

Table 1. Characteristics of the study sample.

\begin{tabular}{|c|c|c|c|}
\hline Variable & Title & Frequencies & Percentage \\
\hline \multirow{5}{*}{ Years of Experience } & Less than 3 years & 10 & $\% 15$ \\
\hline & 3 -less than 6 years & 12 & $\% 17$ \\
\hline & 6 - less than 10 years & 16 & $\% 23$ \\
\hline & 10 years and more & 31 & $\% 45$ \\
\hline & sum & 69 & $\% 100$ \\
\hline \multirow{4}{*}{ Specialization } & Accounting & 35 & $\% 51$ \\
\hline & Administration & 20 & $\% 29$ \\
\hline & Other & 0 & 0 \\
\hline & sum & 69 & $\% 100$ \\
\hline \multirow{4}{*}{ Qualification } & diploma & 0 & 0 \\
\hline & BA & 49 & $\% 71$ \\
\hline & Postgraduate & 20 & $\% 39$ \\
\hline & sum & 69 & $\% 100$ \\
\hline
\end{tabular}

It is noted from Table 1 that the majority of the sample of the sample have suitable experience, as $45 \%$ have more than 10 years' experience and this is a positive indicator of the subject of the study, as the agile accounting and internal control are positively affected by the years of experience. It is also noted that the scientific specialization of accounting is the highest category, as the sample of the study is the internal auditors in the Jordanian industrial companies, and it is natural that their specialization in the field of accounting. It questionnaire according to the Kronbach Alpha test (79\%) is acceptable to the results of the present study, since the acceptable rate of generalization of the results of such studies is $70 \%$.

Table 2. The views of the study sample by the variable of the accounting control.

\begin{tabular}{|c|c|c|c|c|}
\hline No & Paragraph & Weighted average & Standard deviation & Rank \\
\hline 1 & $\begin{array}{l}\text { When inventory costs are at their lowest levels of lean production, they contribute } \\
\text { to maintaining the integrity of the I and the financial statements }\end{array}$ & 3.45 & 0.52 & 3 \\
\hline 2 & $\begin{array}{l}\text { Indirect costs play an important role in lean production, which contributes to the } \\
\text { overall control and control of accounting applications }\end{array}$ & 3.89 & 0.49 & 2 \\
\hline 3 & $\begin{array}{l}\text { Products are re-formed during operational production processes, contributing to } \\
\text { the continuous tracking of financial and accounting processes }\end{array}$ & 4.25 & 0.76 & 1 \\
\hline 4 & $\begin{array}{l}\text { Rapid manufacturing is growing with relative stability in the size of one point, } \\
\text { which contributes to increasing the efficiency of accounting staff }\end{array}$ & 2.49 & 0.68 & 5 \\
\hline 5 & $\begin{array}{l}\text { An analysis of cost elements and data that affect lean production contributes to the } \\
\text { separation of competing competencies between accounting staff }\end{array}$ & 3.05 & 0.83 & 4 \\
\hline 6 & $\begin{array}{l}\text { The process of determining the appropriate price of the commodity based on } \\
\text { market factors, contributes to the establishment of a system of moral and material } \\
\text { protection of the assets of the industrial company }\end{array}$ & 2.26 & 0.64 & 6 \\
\hline \multicolumn{2}{|c|}{ Weighted average } & 3.23 & 0.65 & \\
\hline
\end{tabular}

Note from the previous table that the third paragraph represents the highest impact with an average of 4.25 and the standard deviation of 0.76 , which is "the products are restructured during the operational production processes, contributes to the tracking of the financial and accounting processes continuously," indicating that the re-manufacturing and production stages according to the wishes Customers have the effect of consistently controlling accounting processes as a result of continuous change in production also notes that the scientific qualification of the study sample have the qualifications of bachelor or postgraduate, Results and sample of the study

\subsubsection{Discuss the Statistical Results of the Study Hypotheses}

The First Hypothesis "There is no effect on the use of lean accounting on the effectiveness of accounting control in Jordanian industrial joint stock companies." 
average of the hypothesis 3.23 , which is higher than the average satisfactory 3 This indicates that the internal auditors in the Jordanian industrial companies confirm the existence of the impact of the accounting grace to achieve the effectiveness of Accounting

The second hypothesis of the study "There is no effect on the use of lean accounting on the effectiveness of administrative control in Jordanian industrial companies"

Table 3. The views of the study sample by the variable of the accounting control.

\begin{tabular}{|c|c|c|c|c|}
\hline No & Paragraph & Weighted average & Standard deviation & Rank \\
\hline 1 & $\begin{array}{l}\text { When inventory costs are at their lowest levels of lean production, they contribute to } \\
\text { maintaining the integrity of the I and the financial statements }\end{array}$ & 3.45 & 0.52 & 3 \\
\hline 2 & $\begin{array}{l}\text { Indirect costs play an important role in lean production, which contributes to the } \\
\text { overall control and control of accounting applications }\end{array}$ & 3.89 & 0.49 & 2 \\
\hline 3 & $\begin{array}{l}\text { Products are re-formed during operational production processes, contributing to the } \\
\text { continuous tracking of financial and accounting processes }\end{array}$ & 4.25 & 0.76 & 1 \\
\hline 4 & $\begin{array}{l}\text { Rapid manufacturing is growing with relative stability in the size of one point, which } \\
\text { contributes to increasing the efficiency of accounting staff }\end{array}$ & 2.49 & 0.68 & 5 \\
\hline 5 & $\begin{array}{l}\text { An analysis of cost elements and data that affect lean production contributes to the } \\
\text { separation of competing competencies between accounting staff }\end{array}$ & 3.05 & 0.83 & 4 \\
\hline 6 & $\begin{array}{l}\text { The process of determining the appropriate price of the commodity based on market } \\
\text { factors, contributes to the establishment of a system of moral and material protection } \\
\text { of the assets of the industrial company }\end{array}$ & 2.26 & 0.64 & 6 \\
\hline \multicolumn{2}{|r|}{ Weighted average } & 3.23 & 0.65 & \\
\hline
\end{tabular}

Note from the previous table that the fifth paragraph represents the highest impact according to the opinion of the sample of the sample of the study with an average of 4.28 and a standard deviation 0.64 , which is that "the flexibility of regulations and instructions as new in the environment of the industrial company contribute to the harmonization of employees to accomplish their work," and this indicates that there A relationship between adapting and harmonizing systems and instructions in a manner that is suitable for the efficient and efficient performance of employees. It is also noted that the second paragraph belittles the second degree of influence according to the opinion of the internal auditors in the Jordanian industrial companies at an average of 4.05, namely, "focusing on the company's industrial strategy that helps maximize profit, contributes to identifying the employees responsible for any event in the preparation of the organizational plan" However, the existence of a clear strategy contributes to the drawing up of the organizational plan that helps in determining the lines of power for employees, and defining their duties and duties. It is also noted that the average hypothesis is 3.56 , which is higher than the supposed average 3 This indicates that the lean accounting has a positive impact on administrative control in industrial companies.

\section{Conclusions and Recommendations}

\subsection{Results}

The study concluded the following recommendations

1. The industrial companies are based on the restructuring of their products from time to time based on customer requests, and this contributes to the achievement of financial control and accounting for production costs

2. The industrial companies focus on the indirect industrial costs to reach the output of the goods in a tight manner, which may help to control these costs and try to reduce them as much as possible, and this gives credibility and consistency of the lists of costs in industrial companies

3. The industrial companies shift the reduction of production costs by reducing the cost of inventory to the lowest levels in order to control the assets and safety of the company and maintain a certain level of quality in the financial statements

4. The existence of flexibility in the regulations and instructions applied in the industrial company have a positive impact to find consistency in the work of employees working in the field of accounting and finance, and this there is some kind of integration in the application of regulations and instructions and maintain the lack of conflict in the work of employees

5. The focus on the company's industrial strategy that helps maximize profits, contributes to the identification of employees responsible for any event in the preparation of the organizational plan, and this helps to find a plan for the prior coordination of the industrialization with the workers in the field of accounting and finance, on the fairness of the financial statements

6. The industrial companies apply the policy of cost and benefit in the design or production of a certain commodity based on the desire of customers, and this contributes to the process of planning costs, in order to facilitate the preparation of planning budgets.

\subsection{Recommendations}

Based on the study results, the study recommends the following

1. The need to review the growth of production in industrial companies from time to time according to market factors and requests and expectations of customers, which helps to increase the efficiency of staff in dealing with developments in manufacturing of goods according to those requirements. 
2. The need to achieve self-control of manufacturing processes by taking the target price and target cost

3. the necessity of achieving the best product for the customers in terms of quality and the appropriate price, which affects positively on the achievement of cost control through the work of planning budgets

4. To apply the subject of the study on the service sectors in view of the advantages offered by the agile accounting.

\section{References}

[1] Adekoya F. Nigeria: Brewery Industry as Driver of ValueChain Investment; $2016 . \quad$ Available: allafrica.com/view/group/main/main/id/00058451.html

[2] Najm, Ahmed Saleh (2019) "The Effect of the Use of lean Accounting on Planning Production Processes in Jordanian Industrial Companies", Master Thesis, Al-Bayt University, Mafraq, Jordan.

[3] Mohammed AL-Sharairi1, Atallah Al-Hosban2 \&Hussam Thnaibat2 (2018)" The impact of the Risks of the Input of Accounting Information Systems on Managerial Control, Accounting Control and Internal Control in Commercial Banks in Jordan, International Journal of Business and Management; Vol. 13, No. 2.

[4] Sief, Abd Aljaleel (2018) "Using lean Accounting Tools to Measure and Evaluate Performance in Health Units in Mosul City, Journal of Jihan University, Erbil, Iraq.

[5] Awadallah, Linda (2018). The Effect of Integration between Resource Consumption Accounting and Agile Accounting System on Cost Reduction "Field Study on Some Food Industries Companies in Sudan", Journal of Economic Sciences, Deanship of Scientific Research, Sudan University of Science and Technology. Suhl, Eds. New York: Academic.

[6] Daferighe, Emmanuel Emeakponuzo. (2018). Lean
Accounting and Waste Management in Brewery Industry in Nigeria, Advances in Research, 15 (1). Kass, R. E. and A. E. Raftery (1995). Bayes Factors. Journal of the American Statistical Association 90, 773-794.

[7] Enoch OK.) 2013. (Lean Accounting and Lean business philosophy in Nigeria: An exploratory research. International Journal of Economics, Finance and Management.

[8] Maskell, B. \& Kennedy, F. (2010). Why do we need lean accounting and how does it work? The Journal of Corporate Accounting \& Finance, March/April, 59-73.

[9] Lopes RB, Freitas F, Sousa. (2015). Application of Lean manufacturing tools in the food and beverage industries. Journal of Technology Management and Innovation and Innovation. 10 (3).

[10] J- Abdeen, Sunni (2017). The Role of lean Accounting in Reducing Production Costs and 44.

[11] Franco, Lucherin. (2017). Exploring the Impact of Lean Manufacturing on Flexibility in SMEs, Journal of Industrial Engineering and Management.

[12] Sheikh Salem, Fouad (2007) "Modern Management Concepts", Jordan Book Center, Amman, Jordan.

[13] Aljuifel, Ahmed Salama (2011) "The Role of Computerized Accounting Information in the Effectiveness of Internal Control in Jordanian Islamic Banks" Master Thesis, Middle East University, Amman, Jordan.

[14] Al-Qdah, Ghassan Mustafa (2008) "Effect of Accounting Information Systems on the Effectiveness of Internal Control in Commercial Banks in Jordan, Master Thesis, Al-Bayt University, Mafraq, Jordan.

[15] Moskov, Stephen (2007) "Accounting Information Systems" translated by Kamal Al-Din Saeed, Dar Al-Marikh Publishing, Riyadh, Saudi Arabia.

[16] Kahala, Joseph and Hanan, Radwan (2004) "Administrative Accounting" International Scientific House and House of Culture for Publishing and Distribution, Amman, Jordan. 